\title{
Applicability of the FDA assay to determine the viability of marine phytoplankton under different environmental conditions
}

\author{
M. Garvey ${ }^{1}$, B. Moriceau ${ }^{1,2}$, U. Passow ${ }^{1, *}$ \\ ${ }^{1}$ Alfred-Wegener Institute for Polar and Marine Research, 27580 Bremerhaven, Germany \\ ${ }^{2}$ Present address: UMR 6539, IUEM, Technopôle Brest-Iroise, 29280 Plouzané, France
}

\begin{abstract}
Knowing which fraction of a phytoplankton population is viable would often be helpful in answering ecological or physiological questions. However, viability stains (1) often do not function properly, especially with diatoms, (2) are rarely used, and (3) frequently appear to give ambiguous results. Here, we investigate the performance of the FDA viability assay in detail and test its applicability for investigating 2 ecologically important questions. The functioning of the assay was tested for several diatom species, as well as for Emiliania huxleyi (coccolithophorid) and Phaeocycstis globosa (Prymnesiophyceae). Additionally, changes in the viability of Thalassiosira weissflogii (diatom) - (1) due to aggregation and (2) during a prolonged stationary phase induced by nutrient limitation - were explored. Whereas the method generated solid results with some species, including T. weissflogii, it was less trustworthy or even totally ineffective with others. Ambiguous definitions of viability and cell death, as well as temporary changes in the strength of the fluorescence signal, complicate the interpretation of viability measurements. However, exiting ecological results can be attained with this method. Experiments with $T$. weissflogii suggested that the vast majority of cells, rather than individual survivors remained viable for over a month in an illuminated, nutrient-devoid environment. Aggregation significantly prolonged the viability of $T$. weissflogii cells compared to non-aggregated cells kept under otherwise identical conditions.
\end{abstract}

KEY WORDS: Viability of phytoplankton · FDA assay $\cdot$ Nutrient limitation $\cdot$ Aggregation

\section{INTRODUCTION}

The competitive success of different phytoplankton species and thus phytoplankton species succession is determined greatly by the mortality rates of individual species. Mortality rates of phytoplankton are, for example, influenced by nutrient availability (Dodson \& Thomas 1977, Berges \& Falkowski 1998), light climate (Peters 1996, Peters \& Thomas 1996, Murphy \& Cowles 1997, Jochem 1999), the presence of environmental pollutants (Bentley-Mowat 1982), grazing (Jansen \& Bathmann 2007), or viral infections (Brussaard et al. 2001). Determinations of the viability (fraction of living cells) of a phytoplankton population are therefore central for ecological or physiological investigations on the succession and survival of phytoplankton. Interpretations of activity parameters, like primary production or exudation rates, are also more meaningful if they can be related to the viable, rather than the total cell concentration. Activity normalized to viable or total cell numbers may differ considerably, because an appreciable fraction of a natural phytoplankton population can be dead (Yentsch 1988, Agustí \& Sánchez 2002, Alonso-Laita \& Agustí 2006). The viability of phytoplankton, however, is not easy to determine.

One main reason is the lack of a clear definition of living and dead cells. The ecological role and the physiological basis of cell death in phytoplankton are not well understood (Franklin et al. 2006). One common definition suggests that the ability to reproduce defines 
a living cell (for detailed discussion on cell death of phytoplankton, see Franklin et al. 2006), but this is frequently hard to test, as the absence of reproduction may well be caused by inadequate environmental conditions, rather than the inability of the cell to reproduce. Furthermore, the distinction between live and dead cells is unclear, as for eukaryotes dying is not an on-off type of process (Franklin et al. 2006). Cell death due to environmentally insufficient conditions (automortality or natural cell death) appears to occur in 3 steps: (1) compromised cell membranes, (2) degradation of photosynthetic pigments, and (3) fragmentation of the genomic DNA (Veldhuis et al. 2001). Accordingly, dying cells with compromised cell membranes but intact photosynthetic pigments may be labeled either viable or dead.

Likewise the definition of dead cells is similarly elusive. In the literature dead diatoms have been defined as including intact but empty frustules, or alternatively dead diatoms have been defined as including only plasma-filled cells (Murphy \& Cowles 1997). Although, in theory, the latter might be the most correct definition, practically a clear distinction between plasmafilled and empty cells is difficult to make, as cells may be partially filled. Others (Agustí \& Sánchez 2002) include only autofluorescing cells in their total counts, thereby comparing viable cells to those which are in the process of dying but not yet dead.

In the past, different stains have been used as an estimate of the viability of cells. Propidium iodide (PI), which is not applicable for phytoplankton, neutral red and Evans blue (Onji et al. 2000), calcein-AM (Brussaard et al. 2001), and fluorescein diacetate (FDA) (BentleyMowat 1982, Onji et al. 2000) are some examples of viability stains. The cell digestion method, which removes dead cells (Agustí \& Sánchez 2002), or Sytox green, a stain that marks dead cells (Veldhuis et al. 2001), have also been used to estimate viability. The different viability assays are based on different principles, and the respective specific definitions of viability are based on the functioning of the respective stain, although many are based on the permeability of the cell membrane.

The FDA assay stains cells fluorescently green that have an intact cell membrane and respiratory activity producing intracellular esterases. All non-FDA-fluorescing cells are considered dead. The assay measures primarily the esterase activity, as it, rather than the membrane permeability, is the rate-limiting factor for the hydrolysis of FDA (Brookes et al. 2000). The FDA assay thus interjects 1 step before assays that are based on compromised cell membranes and has also been used as a measure of metabolic vigor (Selvin et al. 1989, Brookes et al. 2000).

The FDA assay has been shown to work well as an indicator of viability in a wide variety of species, but inter- and intra-specific variability is high, and the stain does not work with all species or even all species of the same group (Bentley-Mowat 1982, Selvin et al. 1989, Murphy \& Cowles 1997, Onji et al. 2000, Agustí \& Sánchez 2002).

As a result of these multifaceted problems, viability stains are not used routinely in marine ecological research, and, when they are utilized, interpretations are easily misguided. The present paper is meant to encourage the use of viability stains by clarifying potential obstacles. We first tested the applicability of the FDA method as a viability stain for 6 marine diatoms, as well as for Emiliana huxleyi and Phaeocystis globosa. We then applied the FDA assay in an attempt to clarify 2 ecologically important issues. First, the temporal change in the viability of Thalassiosira weissflogii kept in the light during an extended stationary phase triggered by nitrogen or silicic acid limitation was monitored. Many phytoplankton cells survive prolonged periods in the dark (Murphy \& Cowles 1997, Lewis et al. 1999), but it is generally assumed that dark, nutrient-replete conditions are a prerequisite for long survival times of marine eukaryotic phototrophs. Secondly, the hypothesis that aggregated cells remain viable for a longer time period than their non-aggregated counterparts was tested. Aggregation and subsequent mass sinking have been proposed to represent an adaptation of marine diatoms to survive high light combined with low nutrient conditions (Smetacek 1985).

\section{MATERIALS AND METHODS}

Experimental set-up. Reliability of the FDA assay as a measure of viability: The reliability of the FDA assay was tested on the coccolithophorid Emiliana huxleyi, which forms large blooms visible from space, on Phaeocystis globosa, a species known for its large, mucus-rich blooms and on 6 species of diatoms. The staining success of the diatoms was tested using batch cultures of Chaetoceros danicus, Chaetoceros decipiens, Coscinodiscus granii, Phaeodactylum tricornutum, Skeletonema costatum, and Thalassiosira weissflogii. Other than P. tricornutum, these species are all important in situ and they span a large range of different cell types, with regard to size, chain formation, and distribution patterns. P. tricornutum was chosen as it is commonly used for laboratory experiments investigating physiological questions. Cultures were grown in $F / 2$, in the case of diatoms with silica (Guillard 1975) at $13^{\circ} \mathrm{C}, 100 \mu \mathrm{mol} \mathrm{m}{ }^{-2} \mathrm{~s}^{-1}$, and in a $12: 12 \mathrm{~h}$ light:dark cycle. The FDA assays were performed when the respective batch cultures were in late exponential or early stationary phase to ensure that both viable and 
dead cells were present in significant numbers. An aliquot of the batch cultures was also fixed with formalin (10\% end concentration) and stained 2 to $5 \mathrm{~d}$ later to ascertain that no false positives occurred.

Nutrient limitation experiment: In this experiment cell concentrations in six 21 batch cultures of Thalassiosira weissflogii were monitored every 1 to $3 \mathrm{~d}$ during (1) exponential growth, (2) the following $30 \mathrm{~d}$ stationary phase, which was reached due to silicic acid or nitrate limitation, respectively (3 replicate batch cultures each), as well as during (3) the renewed exponential growth caused by re-addition of the limiting nutrient. Initial nutrient concentrations in silicic-acidand nitrogen-limited cultures were 24 and $200 \mu \mathrm{M}$ silicic acid and 200 and $26 \mu \mathrm{M}$ nitrate, respectively. Initial phosphate concentrations were $18 \mu \mathrm{M}$ in all cultures; vitamins and trace elements were added as in $F / 2$. Nutrient limitation of growth was confirmed by addition of silicic acid $(125 \mu \mathrm{M})$ and nitrate $(90 \mu \mathrm{M})$, respectively, after $30 \mathrm{~d}$ in stationary phase. Cultures were grown at $50 \mu \mathrm{mol} \mathrm{m}{ }^{-2} \mathrm{~s}^{-1}$ in a 16:8 h light:dark cycle during all phases of the experiment. Viability was determined several times during exponential phase and every 1 to $3 \mathrm{~d}$ during the stationary phase.

Aggregation experiment: The effect of aggregation on the viability of cells was tested using Thalassiosira weissflogii. Before the onset of the experiment, nutrient concentrations in the surrounding media were reduced by letting cells of the batch culture grown in $F / 2$ settle and exchanging about $80 \%$ of the media for nutrientdeplete artificial seawater. During the experiment nutrient concentrations in the media were then comparable to seawater concentrations (e.g. $20 \mu \mathrm{M}$ silicic acid). Then, the batch culture, which was in late stationary phase was divided, and 1 aliquot (2 l) was incubated on a roller table $(\mathrm{rpm}=0.5)$ to promote aggregation (Shanks \& Edmondson 1989), whereas the second aliquot (1.5 l) was kept on a rotating table, which oscillated at $2.9 \mathrm{~Hz}$ to keep cells freely suspended and nonaggregated. Both treatments were incubated in the dark at $13^{\circ} \mathrm{C}$ to mimic sinking in the ocean. Cells incubated on the rotating table remained in suspension and freely dispersed during the whole experiment. After $72 \mathrm{~h}$, approximately 20 aggregates were visible in the roller tank. Samples were taken every 1 to $3 \mathrm{~d}$ for $24 \mathrm{~d}$ from both treatments for immediate viability assessment with FDA. Aggregated cells were collected with a syringe stuck through a rubber stopper on the flat side of the roller table. Freely suspended cells were also sampled with a syringe. Aggregated cells had to be disaggregated before counting by gentle shaking. The effect of the procedure used for disaggregation on the viability of cells was checked beforehand.

Analysis. FDA assay: The FDA (fluorescein diacetate) assay is based on the cleavage of fluorescein diacetate in cells actively respiring. Non-polar, hydrophobic FDA (MW 416) is hydrolyzed by non-specific esterases, yielding fluorescein upon penetrating an intact cell membrane. The polar fluorescein product is retained within the intact cell membrane (BentleyMowat 1982). The retained fluorescein fluoresces green under blue-light excitation. The percentage of viable (fluorescing) cells may be determined microscopically, using flow cytometry (Jochem 1999) or a spectrofluorometric reader (Gilbert et al. 1992).

The FDA stock solution was prepared by mixing $50 \mathrm{mg}$ FAD (Sigma) in $10 \mathrm{ml}$ dimethylsulfoxide (DMSO). This stock solution was frozen in a refrigerator at $7^{\circ} \mathrm{C}$ (DMSO freezes at this temperature) and was thawed each day for the preparation of a working solution (Jochem 1999). Prepared directly before usage, the working solution was obtained by diluting the stock solution 100 times with chilled distilled water. A maximum of 5 samples was inoculated each day by adding $100 \mu \mathrm{l}$ of the working solution to $3 \mathrm{ml}$ sample (end concentration: $1.7 \mu \mathrm{g} \mathrm{ml}^{-1}$ FDA). Samples containing aggregates were gently shaken to break up the aggregates and then diluted by a factor of 3 with $0.2 \mu \mathrm{m}$ filtered artificial seawater, before addition of the staining solution. Stained samples were kept cool and dark for at least 10 min before enumeration and could be saved for up to 90 min without risking significant fluorescent degradation if kept in the dark and in an ice-bath. This was tested by repeated counts over a 90 min interval.

Viability counts: The fraction of FDA-stained cells (viability) was determined under a Zeiss Axiovertfluorescence microscope (Axioskop 2 plus) at $100 \times$ to $400 \times$ magnification, depending on cell size. High magnifications were chosen because it was important to be able to distinguish mitochondrial activity from chlorophyll fluorescence. At least 200 cells were counted over 10 to 100 fields of vision, depending on cell size and concentration. Cells were counted in several, overlapping categories: in each field of vision, the total number of cells that were intact and the number of cells that were obviously empty were counted under visible white light. Then, within the same field of vision, the number of cells that showed green-fluorescence (wavelengths 520 to $530 \mathrm{~nm}$ ) and the number of cells with red autofluorescence were counted under blue-light excitation (wavelengths 450 to $500 \mathrm{~nm}$ ). Viability was defined as the fraction of green fluorescent cells to the total number of visually intact (empty or plasma filled) cells, except where stated otherwise. Intact empty frustules are included because a distinction between empty and cell-organelle-containing frustules is fraught with practical problems. Such a distinction cannot even be attempted with Coulter counters, and a continuum with partially empty frustules makes the decision difficult for any microscopist. 
Total cell numbers: Total cell concentrations were enumerated with a Coulter counter (Multisizer 2) for the nutrient limitation experiment and manually, using an inverted microscope (Zeiss IM35) following the method of Utermöhl (1958), during the aggregation experiment. Formalin-fixed (4\% final concentration) samples were settled in $3 \mathrm{ml}, 26 \mathrm{~mm}$ diameter chambers (Hydro-bios Kiel) for over $2 \mathrm{~h}$ before enumeration. Counting was performed at 160× magnification, and a minimum of 300 cells was counted (Lund et al. 1958).

\section{RESULTS AND DISCUSSION}

\section{Performance of the FDA viability assay for different species of marine phytoplankton}

Although the FDA assay has in the past been used successfully with some species of marine phytoplankton (Table 1), we found the method to produce unreli- able and random results (e.g. lack of replication, absence of patterns) when attempting to use it on diatoms during an earlier experiment. We therefore tested its reliability for some common phytoplankton species before running further experiments. The following criteria were used to evaluate the reliability of the FDA assay as a measure of viability: (1) The green fluorescence in cells had to be clearly visible. Masking by red autofluorescence is a common problem of the method (Bentley-Mowat 1982, Agustí \& Sánchez 2002). (2) The green fluorescence had to remain visible long enough for reliable counts $(<5$ min for each field of vision, $<30$ min for each slide). (3) It was also pertinent that formalin-fixed cells (cells with an impaired cell membrane) gave no false positives. Green fluorescence is never observed, although red autofluorescence may remain strong for weeks or months after cells are fixed with formalin. According to these 3 criteria, the FDA microscopy assay was effective in 5 of the 8 species tested.

Table 1. Summary of fluorescein diacetate (FDA) assay of marine eukaryotic phytoplankton. +: FDA assay works; -: FDA assay does not work. In cases where the success of the FDA assay is given in more than 1 paper, + and - symbols are given in the same order as the respective citations. Thirty more Dinophyceae were tested by Selvin et al. (1989), and did exhibit FDA signals, except for Gyrodinum aureolum. However, staining in many species was 'irregular', and the reasons for this inconsistent staining of the population remain unclear

\begin{tabular}{|c|c|c|c|}
\hline Species & Family & FDA & Source \\
\hline Chaetoceros decipiens & Bacillariophyceae & + & Present study \\
\hline Chaetoceros danicus & Bacillariophyceae & + & Present study \\
\hline Chaetoceros socialis & Bacillariophyceae & + & Onji et al. (2000) \\
\hline Chaetoceros spp. & Bacillariophyceae & + & Bently-Mowat (1982) \\
\hline Coscinodiscus granii & Bacillariophyceae & + & Present study \\
\hline Coscinodiscus sp. & Bacillariophyceae & + & Bently-Mowat (1982) \\
\hline Phaeodactylum tricornutum & Bacillariophyceae &,,,--+- & $\begin{array}{l}\text { Bently-Mowat (1982), Onji et al. (2000), } \\
\text { Agustí \& Sánchez (2002), Present study }\end{array}$ \\
\hline Thalassiosira weissflogii & Bacillariophyceae &,++ & Murphy \& Cowles (1997), Present study \\
\hline Thalassiosira sp. & Bacillariophyceae & + & Agustí \& Sánchez (2002) \\
\hline Skeletonema costatum & Bacillariophyceae &,,-++ & $\begin{array}{l}\text { Bently-Mowat (1982), Onji et al. (2000), } \\
\text { Present study }\end{array}$ \\
\hline Ditylum brightwellii & Bacillariophyceae & + & Bently-Mowat (1982) \\
\hline Biddulphia spp. & Bacillariophyceae & + & Bently-Mowat (1982) \\
\hline Melosira spp. & Bacillariophyceae & + & Bently-Mowat (1982) \\
\hline Cerataulina bergonii & Bacillariophyceae & + & Bently-Mowat (1982) \\
\hline Alexandrium catenella & Dinophyceae & + & Onji et al. (2000) \\
\hline Gymnodinium mikimotoi & Dinophyceae & + & Onji et al. (2000) \\
\hline Heterosigma akashiwo & Dinophyceae & + & Onji et al. (2000) \\
\hline Prorocentrum minimum & Dinophyceae & + & Onji et al. (2000) \\
\hline Prorocentrum micans & Dinophyceae & + & Onji et al. (2000) \\
\hline Chatonella marina & Dinophyceae & + & Onji et al. (2000) \\
\hline Heterocapsa sp. & Dinophyceae & + & Agustí \& Sánchez (2002) \\
\hline Emiliania huxleyi & Prymnesiophyceae &,++ & Agustí \& Sánchez (2002), Present study \\
\hline Phaeocystis globosa & Prymnesiophyceae & - & Present study \\
\hline Phaeocystis sp. & Prymnesiophyceae & + & Agustí \& Sánchez (2002) \\
\hline Hymenomonas elongate & Haptophyceae & + & Bently-Mowat (1982) \\
\hline Isochrsis galbana & Haptophyceae & + & Bently-Mowat (1982) \\
\hline Dunaliella primolecta & Chlorophyceae & + & Bently-Mowat (1982) \\
\hline Dunaliella spp. & Chlorophyceae & + & Agustí \& Sánchez (2002) \\
\hline Clorella sp. & Chlorophyceae & + & Agustí \& Sánchez (2002) \\
\hline Tetraselmis spp. & Prasinophyceae &,++ & Bently-Mowat (1982), Onji et al. (2000) \\
\hline
\end{tabular}


Emiliania huxleyi, Chaetoceros decipiens, Chaetoceros danicus, Thalassiosira weissflogii, and Coscinodiscus granii met the criteria, indicating that the FDA assay could be used to determine the degree of viability of these species. Similar to our results BentleyMowat (1982) and Onji et al. (2000) had positive results with different Chaetoceros species, and Murphy \& Cowles (1997) found the FDA assay to work with $T$. weissflogii. The ease of applicability, however, differed appreciably between species. T. weissflogii showed the most distinguishable and reliable response to the method, whereas the counting required a greater detail of scrutiny for C. granii, for example, because red autofluorescence tended to overshadow the green FDA fluorescence (Fig. 1).

Autofluorescence may even interfere with counts of green FDA fluorescence in individual samples of species in which counting the green fluorescence is generally considered easy. Twice in over 120 samples the red chlorophyll a (chl a) autofluorescence of Thalassiosira weissflogii was so bright that, at first sight, viability appeared very low, as the green fluorescence was masked. Only a careful investigation of each cell at higher magnification revealed that cells were clearly fluorescing green. This phenomenon was observed twice in 1 of the replicate nitrate-limited treatments during the nutrient limitation experiment. It is unclear what caused this intense red autofluorescence at these times.

The FDA microscopy method could not be applied to Phaeodactylum tricornutum or Phaeocycstis globosa
(Table 1), because their intense autofluorescence made reliable observation of green fluorescence impossible, even when the FDA stain was used at higher concentrations. The results for $P$. tricornutum are in agreement with those of Bentley-Mowat (1982) and Agustí \& Sánchez (2002), but disagree with those of Onji et al. (2000), who reported successful counting of $P$. tricornutum. The usage of Filter Set 44 (excitation BP 475/40, beamsplitter FT 500, emission BP 530/50; Zeiss) selectively masks the red autofluorescence, but appears to result in rapid fading of the green FDA fluorescence (Jansen \& Bathmann 2007).

The second frequently encountered problem using the FDA assay was the rapid fading of the green fluorescence. The intensity of the fluorescence decreases due to exposure of light and with time. Reproducible results for species that show a weak FDA signal, like Chaetoceros granii, may be generated by following a very strict protocol, and counting within a short, constant time period after staining. The very rapid fading of the FDA green fluorescence made counts of the green fluorescence for Skeletonema costatum, however, impossible. This finding appears to contradict previous reports that $S$. costatum showed a positive response with the FDA microscopy assay (BentleyMowat 1982, Onji et al. 2000). However, BentleyMowat (1982) also noted a wide variability in fluorescent staining in non-actively growing populations of $S$. costatum, and attributed this to a large fraction of 'moribund' cells. The growth phase of cells investi-
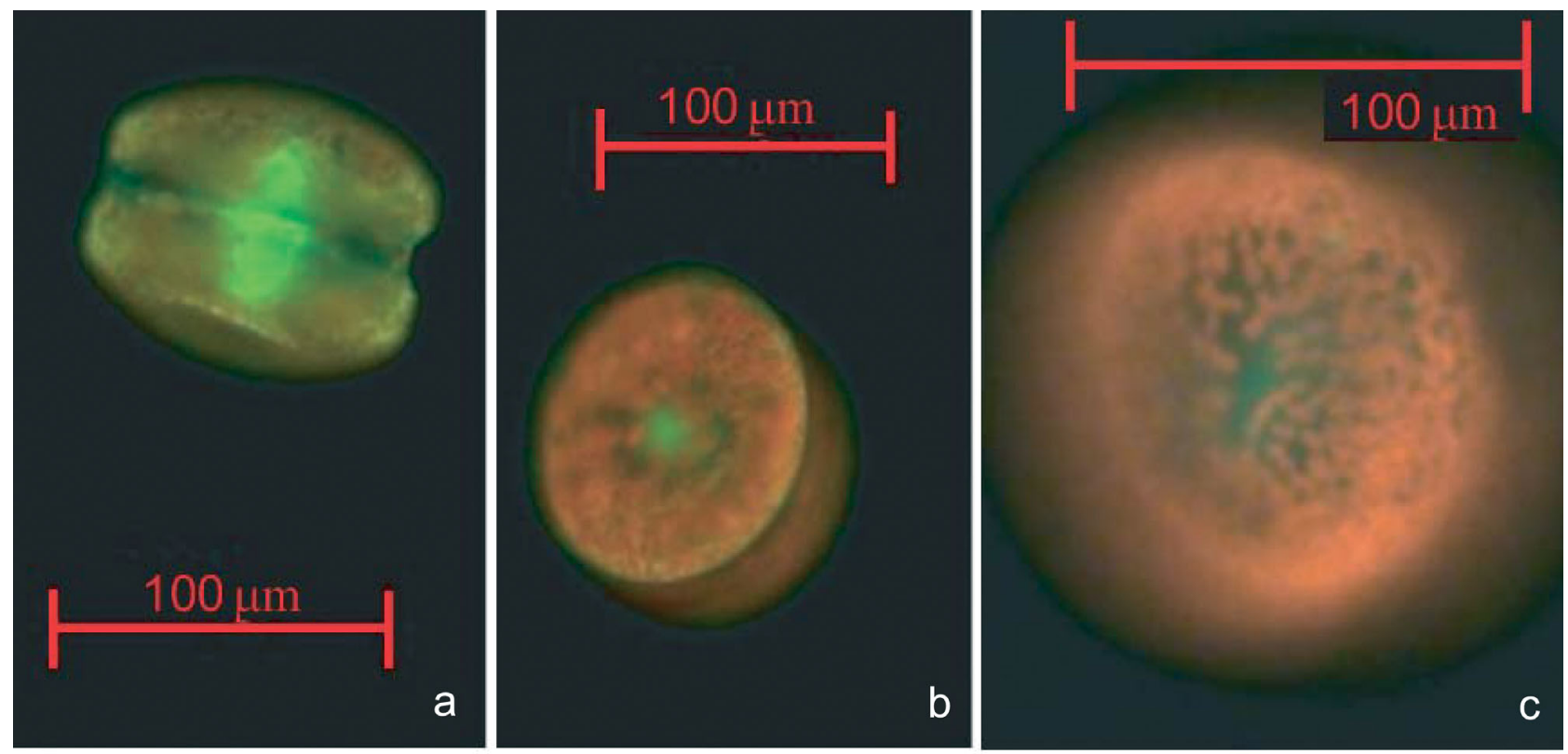

Fig. 1. Coscinodiscus granii. Photographs of C. granii stained with fluorescein diacetate (FDA) and viewed under blue light. The red autofluorescence is so strong that, depending on the angle at which the cell is observed, the green FDA fluorescence can be obscured. (a) Green fluorescence is clear from the side view, but (b) hidden from the top view, and (c) disappears under exposure to white light 
gated by Onji et al. (2000) was not noted, but possibly the fluorescent signal may be strong enough to appear reliable during exponential growth, whereas, during non-growth phases, the FDA signal may be weak and ambiguous.

The handling of the cells before or after staining also affects the utility of the FDA assay. The method was used successfully for counting aggregated Thalassiosira weissflogii, but did not work for aggregates of Chaetoceros decipiens cells. We found that by shaking aggregates of $T$. weissflogii, these cells were easily disaggregated for counting without damaging cells due to the fluffy nature of those aggregates combined with the sturdy nature of the individual cells. The more fragile cells of $C$. decipiens, however, were damaged during all attempts to disaggregate the very sticky aggregates, creating artificially low viability counts for aggregated $C$. decipiens cells. We choose $T$. weissflogii to monitor the effectiveness of the viability stain during experiments on changing viability due to environmental factors.

\section{Changes in the viability of Thalassiosira weissflogii kept under silica- or nitrogen-limited conditions in the light}

Cell concentrations of $T$. weissflogii in both treatments (and each of the 3 replicates) increased exponentially. After 10 to 11 and 11 to 13 d, respectively, nitrate and silicic acid concentrations in the 3 nitrogenand 3 silica-limited cultures were below detection (De La Rocha \& Passow 2004). Peak cell concentrations of 22000 to 25000 cells ml ${ }^{-1}$ were reached by Days 11 to 13, when the cultures entered stationary phase (De La Rocha \& Passow 2004). Viability of exponentially growing cultures in all 6 experiments was usually 85 to $95 \%$ (Fig. 2). During the $30 \mathrm{~d}$ of stationary phase, cell concentrations in both treatments decreased only slightly, by, on average, $0.5 \pm 0.3 \% \mathrm{~d}^{-1}$. The viability of cells also remained high and did not differ between treatments. Except at a few individual sampling points (see below) viability ranged between 80 and $95 \%$ during the whole $30 \mathrm{~d}$ of stationary phase, but variability within this range was high. After 30 to $35 \mathrm{~d}$, the respective limiting nutrients, which had remained below detection, were added again, and exponential growth resumed within 1 to $2 \mathrm{~d}$, confirming that cultures were indeed nutrient-limited before.

Many diatoms, or at least a small fraction of their respective populations, are known to survive prolonged periods of darkness, in sediments (Lewis et al. 1999) or in the water, both in their vegetative state (Peters 1996, Peters \& Thomas 1996 and citations within) and as spores (Durbin 1978, Hollibaugh et al.
1981), as evidenced by their ability to resume growth upon re-exposure to light or as shown with the FDA assay (Murphy \& Cowles 1997). Survival times in the dark are species specific and vary between $1 \mathrm{~m}$ and almost 1 yr (Peters 1996). However, survival under nutrient-deplete conditions in the light has been assumed to be low (Smetacek 1985), although prolonged survival under oligotrophic conditions of at least a small fraction of cells of Thalassiosira weissflogii (Berges \& Falkowski 1998), Chaetoceros affinis (diatom) and Gymnodinium splendens (dinoflagellate) (Dodson \& Thomas 1977) has been shown. Our results demonstrate that the bulk of a population of $T$. weissflogii remains viable for at least 1 mo during either nitrogen or silicic acid limitation in the light. Survival was the same under nitrogen and silicic acid limitation, although silicic acid is not required by the cells in the absence of cell division, whereas nitrogen is needed for a suite of metabolic processes. Possibly, efficient recycling of ammonia contributed enough nitrogen for cells to remain viable. Extended survival under nitrogen-deplete conditions in the light may also have been possible as a result of mixotrophy or the usage of storage products.

Although viability in the majority of the samples remained high during the investigation, a temporary drop in viability to $\leq 65 \%$ was observed between 2 and $4 \mathrm{~d}$ after the onset of the stationary phase in 1 of the silicalimited cultures and in all 3 of the nitrogen-limited replicates (Fig. 2b,d-f). These sudden, short-lived drops in viability did not mirror mass death events, as the corresponding decreases in cell numbers were not of sufficient magnitude to justify the assumption of cell death and as the viability recovered to high values within 1 to $2 \mathrm{~d}$. Rather, it appeared that $25 \%$ of 'non-viable' cells during this transition phase were actually still viable, but exhibited viability below the detection limit of the FDA assay. As the esterase activity is the rate-limiting step for FDA fluorescence, brief episodes of 'low viability' without a concomitant decrease in cell numbers must be the result of a transient decrease in esterase concentration or activity. Gilbert et al. (1992) also observed that the intensity of the FDA fluorescence per cell varied, and found that fluorescence of Tetraselmis suecica was high before the exponential phase, dropping appreciably during the growth phase. It was assumed that cells were undergoing different metabolic pathways during the rapid growth phase, thereby impacting the fluorescence signal. This confines the applicability of the FDA assay as a viability stain, as variations in the strength of the green fluorescence depending on the physiological vigor of the cells blur the definition of a living cell. These results also suggest some interesting physiological responses of cells to the onset of nutrient limitation. 

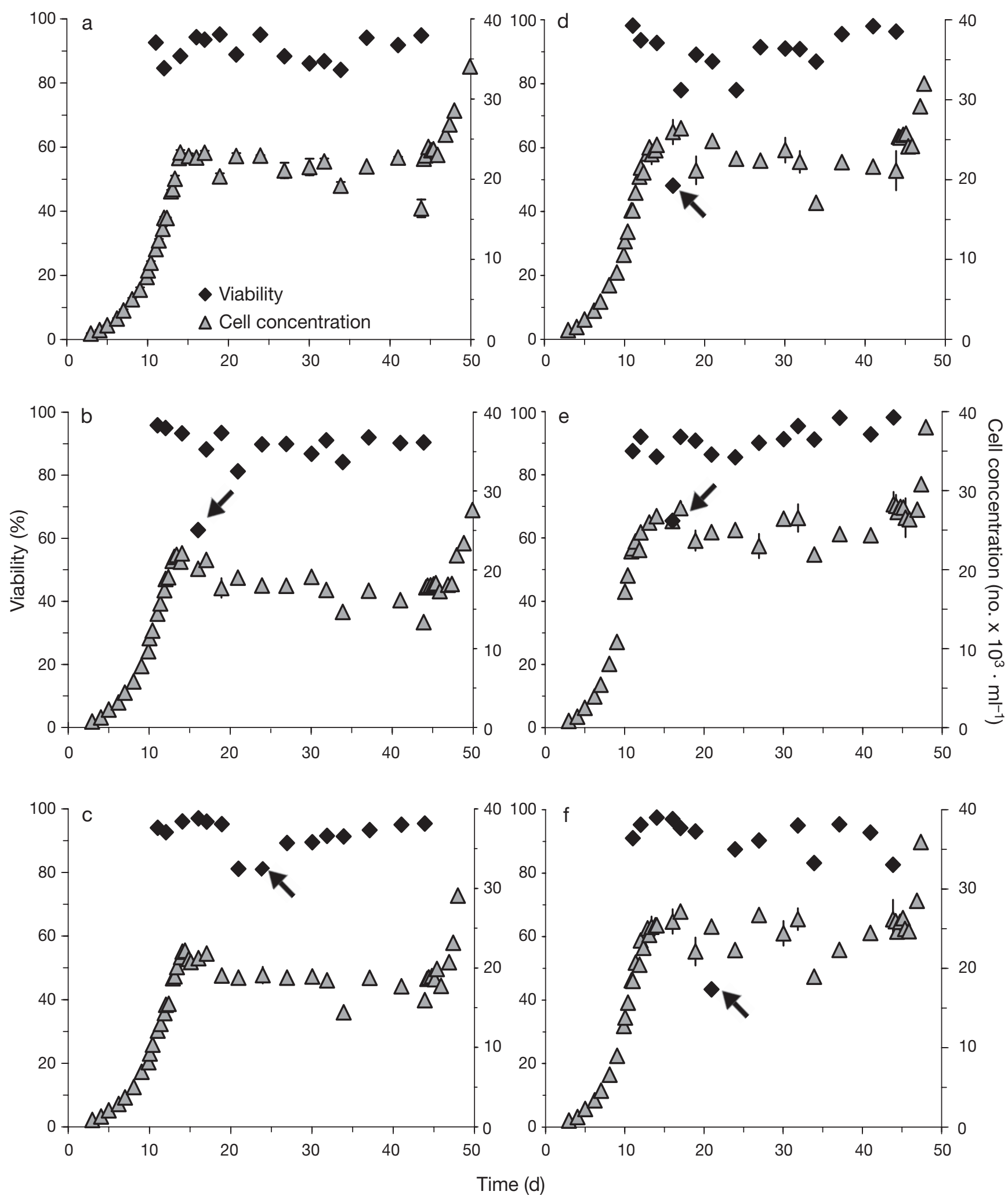

Fig. 2. Thalassiosira weissflogii. Cell concentrations (no. of cell) and cell viability (ratio of green fluorescent cells to total number of intact cells) of 6 batch cultures during exponential growth, the subsequent stationary phase due to nutrient limitation and the renewed growth period after nutrient re-addition. $(\mathrm{a}, \mathrm{b}, \mathrm{c})$ replicates for silicic acid limitation; $(\mathrm{d}, \mathrm{e}, \mathrm{f})$ nitrate-limited replicates. Arrows mark the transient low-viability events discussed in 'Results and discussion'. A transient decrease in viability, although less pronounced, is also visible in Panel b. Error bars depict SD, but were frequently smaller than the symbol 


\section{Changes in viability of Thalassiosira weissflogii due to aggregation}

These experiments were conducted with old cultures of Thalassiosira weissflogii that were rich in empty or partially empty frustules, which was reflected in the low initial viability $(40 \%$ of all intact cells or frustules were FDA positive). The viability of non-aggregated cells decreased steadily at a rate of approximately $0.08 \% \mathrm{~h}^{-1}$ from the onset of the experiment, reaching a viability of only $3 \%$ after $24 \mathrm{~d}$ (576 h) (Fig. 3a). Changes in viability of aggregated cells, however, differed. Initially a similar decrease in viability was observed as cells aggregated, but viability recovered to about $40 \%$ within a couple of days, suggesting that this initial decrease reflected a transient event connected to the transition phase caused by aggregation. Similar to the transition from exponential to stationary growth observed in the prior experiment, the viability stain mimicked cell death during this transition caused by aggregation, although no cell death occurred. After this transient event, viability of aggregated cells remained almost constant during the first $12 \mathrm{~d}$ of the experiment, with the viability of the population fluctuating between 35 and $40 \%$. After $12 \mathrm{~d}$, the difference in viability between freely suspended and aggregated cells reached a maximum of $22 \%$. After Day 12, viability of aggregated cells began decreasing at a rate of about $0.10 \mathrm{~h}^{-1}$ until reaching a viability of about $8 \%$ by the end of the experiment (Day 24).

These results imply that aggregation of cells in the dark under nutrient-limited conditions retards cell death. Viability decreased 12 d later in aggregated cells compared to non-aggregated ones in the same physiological state. Aliquots used for aggregated and freely suspended cell treatments stemmed from the same batch culture and were kept under identical environmental conditions, with the exception of the motion under which cells were kept. Differences in the motion that the cells were subjected to were necessary to aggregate cells in 1 treatment or keep them from aggregating in the other. Theoretically, water movement within a roller table is negligible after solid body rotation is established, and coagulation is dominated by differential settling. The rotating table used to keep non-aggregated cells in suspension is routinely used to keep diatoms in batch cultures from settling to the bottom of the flask. The flasks rotated over an arc of about $1 \mathrm{~cm}$ rather than through their center, providing gentle motion to cells. Very little is known about the direct effect of motion on phytoplankton cells. Here, we assume that the difference in survival was directly related to the state of aggregation, not due to differences in shear.

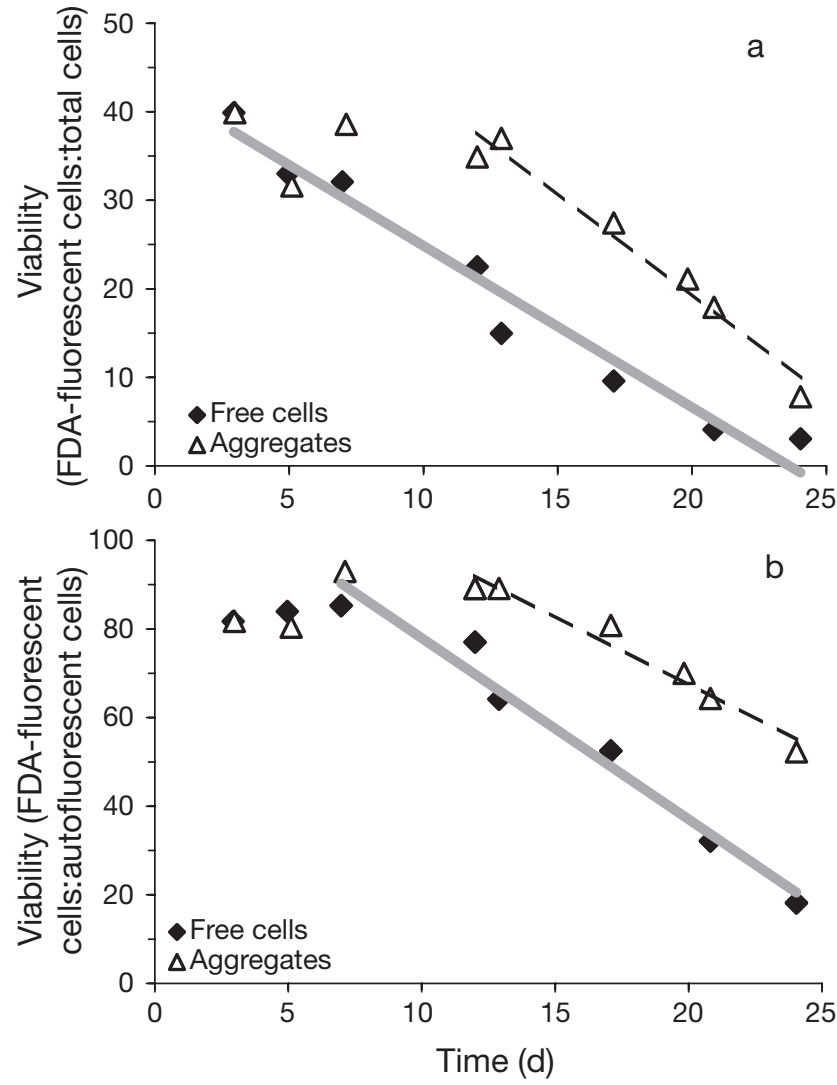

Fig. 3. Thalassiosira weissflogii. Viability over time as a function of aggregation of cells. Viability may be calculated as the proportion of FDA-positive cells compared (a) to total cell numbers or (b) to cells that exhibit red autofluorescence. (a) The linear regression (dashed black line; $y=-0.01 x+65 ; \mathrm{r}^{2}=$ 0.97 ) representing the decrease in viability of aggregated cells starts at Day $12(288 \mathrm{~h})$, whereas that (continuous grey line; $y=-0.08 x+43 ; \mathrm{r}^{2}=0.96$ ) representing the decrease in viability of freely suspended cells begins $3 \mathrm{~d}(72 \mathrm{~h})$ after inoculation of cells at the first sampling point as soon as aggregates had formed. (b) The linear regression calculated for the decrease in viability of aggregated cells (dashed black line; $y=$ $\left.-0.13 x+129 ; r^{2}=0.96\right)$ starts at Day $12(288 \mathrm{~h})$, whereas that of freely suspended cells starts at Day $7(168 \mathrm{~h}$; continuous grey line; $y=-0.17 x+119 ; r^{2}=0.97$ )

Aggregation and subsequent mass sinking has been proposed to represent an adaptation of marine diatoms by transporting cells to the nutrient-richer environment found at depth (Smetacek 1985). Since then it has been found that nutrient concentrations in the pore water of natural aggregates are elevated compared to those of the surrounding water (Gotschalk \& Alldredge 1989, Brzezinski et al. 1997). Possibly higher nutrient concentrations within aggregates increase the survival time of cells (Gotschalk \& Alldredge 1989, Moriceau et al. 2007). The higher viability of cells enclosed within aggregates is consistent with the idea of aggregates as hot spots of activity (Azam 1998) and has far-reaching 
implications, not only for their life cycle and reseeding, but also for the recycling of carbon and silica. An extension of the survival time of cells by 1 to $2 \mathrm{wk}$ is extremely advantageous in fast-changing environments. Upwelling events, for example, often occur on time scales of days to weeks, but a diatom may only profit from upwelling if the cell has remained viable through the oligotrophic period, either by aggregation or by survival within the euphotic zone. Prolonged survival will retard the onset of degradation and dissolution. Retarded degradation (Passow et al. 2003) or dissolution (Ragueneau et al. 2006) of aggregated compared to freely suspended cells or frustules implies that recycling takes place at greater depths, thereby changing the biochemical cycling and flux of elements to depth considerably.

\section{How the definition of cell death affects results}

The definition of dead cells affects viability measurements appreciably. Murphy \& Cowles (1997) defined dead cells as 'FDA negative', and, although they do not describe what this means, it may be assumed that intact cells and empty frustules are included in their total counts as we have done. Agustí \& Sánchez (2002), however, defined a dead cell as having no green fluorescence, but active pigment autofluorescence, which simplifies counting considerably, but may give arbitrary results. A comparison elucidates differences based on the definition of dead cells: using the definition including only cells with active autofluorescence in total counts means that in our aggregation experiment initially about $80 \%$ of all freely suspended and aggregated cells were viable (instead of $40 \%$ ) and in contrast to the prior definition remained so for the first 5 to $6 \mathrm{~d}$ (Fig. 3b). After $7 \mathrm{~d}$ $(167 \mathrm{~h})$, freely suspended cells began dying with a steady decline in viability of $0.17 \% \mathrm{~h}^{-1}$ (compared to $0.08 \% \mathrm{~h}^{-1}$ ), until, at the end of the experiment, only $18 \%$ of all autofluorescing freely suspended cells were FDA positive. The proportion of FDA-positive, aggregated cells conversely increased after about $5 \mathrm{~d}$ (125 h) by approximately 10 to $>90 \%$ and remained at this level for $12 \mathrm{~d}(288 \mathrm{~h})$, after which viability began decreasing at a slower rate of $0.13 \% \mathrm{~h}^{-1}$ (compared to $0.10 \% \mathrm{~h}^{-1}$ ). This direct comparison (Fig. 3a,b) of changes in viability based on different definitions of dead cells shows that, in our study, the overall result that aggregation retards cell death was independent of the definition of dead cells. Timing and absolute and relative rates, however, differed. The main result was similar because the degradation of photopigments was small during this short-term experiment. However, under different circumstances, measured viability including only autofluorescing cells in the dead cell count may provide meaningless values.

One step toward cell death includes the degradation of photosynthetic pigments, thereby increasing the ratio between green and red fluorescing cells, erroneously implying an increase in the measured viability if it is defined according to Agustí \& Sánchez (2002). In other words, the definition of dead cells based on autofluorescence includes cells which have recently moved towards cell death (first step), but not those which have undertaken the second step. Moreover, once the cell membrane is damaged, the pigments within are susceptible to bacterial degradation at any time. As the degradation of photopigments sets in after an unknown varying span of time, the number of autofluorescing cells without FDA fluorescence does not relate to the time span since cell death was initiated.

\section{CONCLUSIONS}

A comparison of the overall success of the microscopic FDA assay in determining the viability of marine phytoplankton (Table 1) suggests that only if the specific problems of individual species are addressed before application of the assay can it give good results and allow new insights into the metabolic reactions of cells to environmental changes. Results from our experiments demonstrate that, even with well-tested species, transient phases of apparently low cell viability may occur during times of physiological changes, e.g. due to nutrient limitation or due to aggregation. Such variability in the strength of the fluorescence will make the masking of the FDA signal by autofluorescence or the fading of the FDA signal an intermittent problem in such species. Consequently, live cells with low esterase activity can easily be mistaken as dead, although they may recover and 'come to life again'. Any handling that stresses the cells may introduce additional artifacts, as cells that are stressed have greater membrane permeability. Additionally, total cell counts need to include all intact cells, as including only autofluorescing cells will give arbitrary results and the distinction between plasma-filled and empty frustules is practically unreliable. However, if used with care, the assay can give great insights into the relationship between the physiological and ecological functioning of phytoplankton cells.

Acknowledgements: We thank the people who made M.G.'s stay at the AWI possible, and P. Assmy and S. Gonzàlez-Gil for comments on an early version of the manuscript. We also thank our reviewers for their time and constructive comments. 


\section{LITERATURE CITED}

Agustí S, Sánchez MC (2002) Cell viability in natural phytoplankton communities quantified by a membrane permeability probe. Limnol Oceanogr 47:818-828

Alonso-Laita P, Agustí S (2006) Contrasting patterns of phytoplankton viability in the subtropical NE Atlantic Ocean. Aquat Microb Ecol 43:67-78

Azam F (1998) Microbial control of oceanic carbon flux: the plot thickens. Science 280:694-696

Bentley-Mowat J (1982) Application of fluorescence microscopy to pollution studies on marine phytoplankton. Bot Mar 25:203-204

Berges JA, Falkowski PG (1998) Physiological stress and cell death in marine phytoplankton: induction of proteases in response to nitrogen or light limitation. Limnol Oceanogr 43:129-135

Brookes JD, Geary SM, Ganf GG, Burch MD (2000) Use of FDA and flow cytometry to assess metabolic activity as an indicator of nutrient status in phytoplankton. Mar Freshw Res 51:817-823

Brussaard CPD, Marie D, Thyrhaug R, Bratbak G (2001) Flow cytometric analysis of phytoplankton viability following viral infection. Aquat Microb Ecol 26:157-166

Brzezinski MA, O'Bryan LM, Alldredge AL (1997) Silica cycling within marine snow. Limnol Oceanogr 42: 1706-1713

De La Rocha CL, Passow U (2004) Recovery of Thalassiosira weissflogii from nitrogen and silicon limitation. Limnol Oceanogr 49:245-255

Dodson AN, Thomas WH (1977) Marine phytoplankton growth and survival under simulated upwelling and oligotrophic conditions. J Exp Mar Biol Ecol 26:153-161

Durbin EG (1978) Aspects of the biology of resting spores of Thalassiosira nordenskioeldii and Detonula confervaceae. Mar Biol 45:31-37

Franklin DJ, Brussaard CPD, Berges JA (2006) What is the role and nature of programmed cell death in phytoplankton ecology? Eur J Phycol 41:1-14

Gilbert F, Galgani F, Cadiou Y (1992) Rapid assessment of metabolic activity in marine microalgae: application in ectotoxicological tests and evaluation of water quality. Mar Biol 112:199-205

Gotschalk CC, Alldredge AL (1989) Enhanced primary production and nutrient regeneration within aggregated marine diatoms. Mar Biol 103:119-129

Guillard RRL (1975) Culture of phytoplankton for feeding marine invertebrates. In: Smith WL, Chanley MH (eds) Culture of marine invertebrate animals. Plenum Press, New York, p 108-132

Hollibaugh JT, Seibert DLR, Thomas WH (1981) Observations on the survival and germination of resting spores of three Chaetoceros (Bacillariophyceae) species. J Phycol 17:1-9

Jansen S, Bathmann U (2007) Algae viability within copepod

Editorial responsibility: Otto Kinne (Editor-in-Chief), Oldendorf/Luhe, Germany faecal pellets: evidence from microscopic examinations. Mar Ecol Prog Ser 337:145-153

Jochem F (1999) Dark survival strategies in marine phytoplankton assessed by cytometric measurement of metabolic activity with fluorescin diacetate. Mar Biol 135: 721-728

Lewis J, Harris ASD, Jones KJ, Edmonds RL (1999) Long-term survival of marine planktonic diatoms and dinoflagellates in stored sediment samples. J Plankton Res 21:343-354

Lund JWG, Kipling, Cren EDL (1958) The inverted microscope method of estimated algal numbers and the statistical basis of estimations by counting. Hydrobiologia 11: $143-170$

Moriceau B, Garvey M, Ragueneau O, Passow U (2007) Evidence for reduced biogenic silica dissolution rates in diatom aggregates. Mar Ecol Prog Ser 333:129-142

Murphy A, Cowles T (1997) Effects of darkness on multiexcitation in vivo fluorescence and survival in a marine diatom. Limnol Oceanogr 42:1444-1453

Onji M, Sawabe T, Ezura Y (2000) An evaluation of viable staining dyes suitable for marine phytoplankton. Bull Fac Fish Hokkaido Univ 51:151-158

Passow U, Engel A, Ploug H (2003) The role of aggregation for the dissolution of diatom frustules. FEMS Microbiol Ecol 46:247-255

Peters E (1996) Prolonged darkness and diatom mortality. II. Marine temperate species. J Exp Mar Biol Ecol 207:43-58

Peters E, Thomas DN (1996) Prolonged darkness and diatom mortality. I. Marine Antarctic species. J Exp Mar Biol Ecol 207:25-41

Ragueneau O, Schultes S, Bidle K, Claquin P, Moriceau B (2006) Si and C interactions in the world ocean: importance of ecological processes and implications for the role of diatoms in the biological pump. Global Biogeochem Cycles 20:GB4S02

Selvin R, Reguera B, Bravo I, Yentsch CM (1989) Use of fluorescein diacetate (FDA) as a single cell probe of metabolic activity in dinoflagellate cultures. Biol Oceanogr 6: 505-511

Shanks AL, Edmondson EW (1989) Laboratory-made artificial marine snow: a biological model of the real thing. Mar Biol 101:463-470

Smetacek VS (1985) Role of sinking in diatom life-history cycles: ecological, evolutionary, and geological significance. Mar Biol 84:239-251

Utermöhl H (1958) Zur Vervollkommnung der quantitativen Phytoplanktonmethodik. Mitt Int Ver Limnol 9:1-38

Veldhuis MJW, Kraay GW, Timmermans KR (2001) Cell death in phytoplankton: correlation between changes in permeability, photosynthetic activity, pigmentation and growth. Eur J Phycol 36:167-177

Yentsch CM (1988) Is only a fraction of natural phytoplankton populations metabolically active? Evidence via the FDA staining protocol. EOS Trans Am Geophys Union 69:1133

Submitted: September 18, 2006; Accepted: June 28, 2007

Proofs received from author(s): November 3, 2007 